INTERNATIONAL JOURNAL OF MULTIDISCIPLINARY RESEARCH AND ANALYSis

ISSN(print): 2643-9840, ISSN(online): 2643-9875

Volume 04 Issue 09 September 2021

DOI: 10.47191/ijmra/v4-i9-08, Impact Factor: 6.072

Page No.- $1247-1254$

\title{
The Influence of Leadership Styles and Work Motivation on Employees Performance of Islamic Banks
}

\author{
Sofyan Bachmid ${ }^{1}$, Ermawati Ermawati ${ }^{2}$ \\ ${ }^{1,2}$ Faculty of Islamic Economic and Business, Universitas Islam Negeri (UIN) Datokarama Palu
}

\begin{abstract}
This paper aims to determine the influence of leadership style and work motivation on employee performance at Bank Mandiri Syariah Palu Indonesia. This study employed a quantitative study, and the data were collected through a survey. There were 48 samples in this study. We used the saturation sampling technique to determine the samples because all populations were recruited for the samples. The data were analyzed using multiple linear regression analysis. The results show that leadership style and work motivation simultaneously affect employee performance at the Bank Mandiri Syariah Palu Indonesia. Among those variables, leadership style has a more significant effect on employee performance. In contrast, work motivation has less influence on employees' work performance, but it still plays a role in the employees' work performance. Our study contributes to better strategy in managing leadership and works motivation to enhance employees' work performances within Islamic banking industries.
\end{abstract}

KEYWORDS: leadership style, work motivation, employee's performances, Islamic banks

\section{INTRODUCTION}

In today's human civilization, all aspects of life cannot be separated from the organization. Organizing is human nature, which means humans are social creatures, and they will not be able to live without other humans [1]. Humans need a community to interact in order to fulfill their needs. Humans usually play a collective role in an organization. When humans are organized, they will interact and become part of the organization where they work, which is a place to harmonize and balance the mission of struggling to prosper their lives [2].

In achieving goals, every organization needs resources to achieve them. These resources include natural, financial, scientific and technological, and human resources. Among these resources, the most important resource is human resources [3]. Human resources are a central instrument in organizations and companies. In order for management activities to run well, companies must have knowledgeable and highly skilled employees and efforts to manage the company as optimally as possible so that employee performance increases.

Employee performance is the result or achievement of an employee's work which is assessed in terms of quality and quantity based on work standards determined by their organization [4]. Good performance is an optimal performance, namely performance that is in accordance with organizational standards and supports the achievement of organizational goals. A good organization is an organization that strives to improve the ability of its human resources because it is a crucial factor in improving employee performance [5].

To achieve organizational goals, employees are required to maximize their performance. Performance is the result of work that has a strong relationship with the organization's strategic objectives, customer satisfaction and contributes to the economy [6]. Thus, performance is about doing work and the results achieved from that work-performance is about what is done and how to do it [7].

There are some negative factors that can reduce employee performance, including the decreased desire of employees to achieve work performance and lack of punctuality in completing work. To avoid the negative factors, employees should obey their organizational rules, pay attention to their environmental pressures, and cooperate with coworkers [8]. In this context, the role of a leader is crucial, and the leader should build the spirit of his employees to achieve company goals [9]. 


\section{The Influence of Leadership Style and Work Motivation on Employees Performance of Islamic Banks}

Organizational leaders have different leadership styles in managing their employees to increase their employees' work performances. Every leader has a strong motivation to ensure his/her employees work with maximum outcomes. A leader's success also depends on his ability to apply a suitable leadership style and the ability to motivate employees to work hard in achieving organizational goals. When an organization has good leadership quality, the organization will achieve its goals quickly.

The relationship between leadership style and work motivation on employees performance within banking industries is limited to study. This study, therefore, conducted research within a national bank branch in Indonesia to understand how the leadership style and work motivation affect employees' performance. Our study contributes to better implementation of leadership style and works motivation in enhancing employees' performance. Our study also contributes to an understanding of bank management of leadership and employees performance within government banking industries in Indonesia.

\section{LITERATURE REVIEW}

\section{A. Leadership Styles}

Every leader basically has different behavior in leading his followers. The leadership behavior is called the leadership style [10]. Leadership style is a way for leaders to manage their subordinates which are expressed in behavior or personality patterns.

A leadership style is also understood as a behavioral norm used by a person when that person tries to influence the behavior of others [11]. Therefore, efforts to harmonize perceptions between those who will influence and those whose behavior will be influenced are very important. There are three leadership styles: authoritarian, democratic, and freestyle (the laisser faire) [12].

\section{Authoritarian Leadership}

The authoritarian leadership style is based on absolute and total power, where a leader concentrates all decisions and policies taken from him in full. All division of tasks and responsibilities is held by the authoritarian leader, while the subordinates only carry out the tasks that have been given.

Authoritarian leadership is also called dictatorship or directive leadership [13]. A leader who adopts the leadership style usually makes decisions without consulting the employees. Authoritarian leadership is based on power or strength inherent in the leader's personality [14]. Authoritarian leadership can be seen from its characteristics, including (a) relying on the strength or power inherited by the leader, (b) considering himself the most powerful, (c) considering himself the most knowledgeable about all issues, other people are considered not to know, (d) decisions that are taken unilaterally, do not recognize compromise so that he does not want to accept suggestions from subordinates, even he does not give the opportunity to subordinates to give suggestions, opinions or ideas, (e) hard in dealing with principles, (f) far from subordinates, (g) prefer subordinates who are abs (as long as you are happy), (h) orders are given by force, (i) supervision is carried out strictly so that orders are actually carried out.

\section{Democratic Leadership}

Democratic leadership is the style of the leader who gives broad authority to subordinates [15]. Whenever there is a problem, the leader always involves subordinates. In a democratic leadership style, the leader provides more information about the duties and responsibilities of his subordinates. In this style, employees have great opportunities for self-development. As such, everyone who is led by this type of leader employee has self-motivation to develop. A leader with a democratic style gives more freedom and flexibility to his subordinates and followers to express their opinions, suggestions, and criticisms and always adheres to democratic values in general.

\section{Liaises Faire Leadership}

The leader usually exhibits a passive style and behavior and also often avoids responsibility [16]. In practice, the leader only submits and provides the instruments and resources needed by his subordinates to carry out a job and to achieve the goals set by the leader. A leader with laize faire style is indeed among his subordinates, but he does not provide motivation, direction, and guidance, and all work is handed over to his subordinates.

A leader with Liaises Faire Leadership style will leave the decision to the wishes of the group; what is good according to the group is the decision. Its implementation also depends on the will of the group. In general, the laissez-faire type is run by leaders who do not have technical expertise. The laissez-faire type has the following characteristics [17]: (a) giving full freedom to subordinates to take actions that are deemed necessary in accordance with their respective fields of duty, (b) the leader does not actively participate in group activities, (c) all work and responsibility is delegated to subordinates, (d) unable to carry out 


\section{The Influence of Leadership Style and Work Motivation on Employees Performance of Islamic Banks}

good coordination and supervision, (e) does not have authority so that he is not feared let alone respected by subordinates, (f) practically the leader does not carry out leadership, he is only a symbol.

\section{B. Leadership in Islamic Perspectives}

Imamah or Islamic leadership is a concept contained in the Qur'an and As-Sunnah, which covers human life from personal, two, family and even human beings or groups [18]. This concept includes both ways of leading and being led for the implementation of Islamic teachings to ensure a better life in this world and the hereafter as the goal. Islamic leadership, it is the nature of every human being that at the same time motivates Islamic leadership. ${ }^{1}$ Allah entrusts humans to be Allah's vicegerents (representatives of Allah) on earth, which is conveyed in the word of Allah SWT in Surah Al-Baqarah 2: verse 30, which states as follows:

"Remember when your Lord said to the Angels: "Indeed I want to make a caliph on earth." They said: "Why do you want to make (the caliph) on earth a person who will make mischief on it and shed blood, even though we always glorify you by praising you and purifying you?" God said: "Indeed, I know what you do not know."

The Qur'an verse above shows the caliph is the representative of God on earth (khalifa fil ardli). The caliph is a human figure who is equipped with the advantages of reason, mind, and knowledge to regulate. The term or the words of this caliph became popularly used after the Messenger of Allah died. In other terms, leadership is also contained in the sense of "Imam", which means religious leaders and spiritual leaders who are imitated and implemented by their fatwas.

The concept of trust given to humans as leaders occupy a central position in Islamic leadership. Logically, if the concept of the caliphate or leader mandate given to humans requires a good relationship or interaction between humans and the trustee (God) [19], namely: (1) doing all God's commands, (2) staying away from all His prohibitions, (3) being happy (sincerely) accept all His laws or provisions. In addition to the relationship with the trustee (God), also build good relationships with fellow human beings and the environment entrusted to him.

Suppose we pay attention to the theories of the function and role of a leader initiated and put forward by scholars. In that case, we will only find that leadership is a concept of interaction, relations, authority processes, and activities to influence, direct, and coordinate only horizontally [20]. The Islamic concept, leadership, is interaction, relations, authority processes, and activities to influence, direct, and coordinate horizontally and vertically [21]. Management theory argues that the function of a leader is as a planner and decision-maker (planning and decision-maker), organizing (organization), leadership and motivation (leading and motivation), supervision (controlling), and others.

Based on the description above, it can be emphasized that Islamic leadership is a process or ability of others to direct and motivate the behavior of others, and there is a cooperative effort in accordance with the Qur'an and Hadith to achieve the desired goals together.

\section{METHODOLOGY}

The approach used in this study is a quantitative approach because this research is focused on knowing the effect of leadership style and work motivation on employee performance. We distributed questionnaires to 48 respondents in a branch of Bank Mandiri Syariah in Palu city, Indonesia. The questionnaire used five Likert scales [22]. The data were analyzed using a statistical package for social studies (SPSS) [23]. Data analysis was carried out through several stages, including validity, reliability, multiple regression test, and classical assumption test.

\section{RESULTS}

\section{A. Respondents Demography}

Our research was conducted at Bank Mandiri Syariah branch in Palu city, Indonesia. The survey questionnaires were distributed to employees of the bank consisted of 48 employees. The description of the survey questionnaires and samples are as follows:

Table 1. Description of Questionnaire

\begin{tabular}{|c|c|c|c|c|}
\hline Number of Samples & Questionnaire Distributed & Returned Questionnaire & Questionnaire Processed & Percentage \\
\hline 48 & 48 & 48 & 48 & $100 \%$ \\
\hline
\end{tabular}

The number of samples used in this study was 48 employees of the bank. The respondents' descriptions are as follows:

${ }^{1}$ Veithzal Rivai, dkk, Pemimpin, 27. 
The Influence of Leadership Style and Work Motivation on Employees Performance of Islamic Banks

Table 2. Respondent Characteristics

\begin{tabular}{|c|c|c|c|}
\hline No & Gender & Amount & Percentage \\
\hline 1 & Male & 18 & $37,5 \%$ \\
\hline 2 & Female & 30 & $62,5 \%$ \\
\hline \multicolumn{2}{|c|}{ Jumlah } & 48 & $100 \%$ \\
\hline
\end{tabular}

\section{Validity and Reliability Test}

The questionnaires were considered valid when the measuring instrument used to obtain data is valid. In contrast, a reliable questionnaire is reliable when used to measure data many times, producing the same data. The validity of the questionnaires are shown in the following table 3 below.

Table 3. Instrument Validity Test Results

\begin{tabular}{|c|c|c|c|c|}
\hline Variable & Statement Items & $\begin{array}{l}\text { Corrected Item } \\
\text { total Correlation }\end{array}$ & $\begin{array}{c}\mathrm{R} \\
\text { Kritis }\end{array}$ & Description \\
\hline \multirow{10}{*}{$\begin{array}{l}\text { Leadership Style } \\
\qquad(\mathrm{X} 1)\end{array}$} & 1 & 0,675 & 0,30 & Valid \\
\hline & 2 & 0,584 & 0,30 & Valid \\
\hline & 3 & 0,715 & 0,30 & Valid \\
\hline & 4 & 0,683 & 0,30 & Valid \\
\hline & 5 & 0,520 & 0,30 & Valid \\
\hline & 6 & 0,623 & 0,30 & Valid \\
\hline & 7 & 0,743 & 0,30 & Valid \\
\hline & 8 & 0,641 & 0,30 & Valid \\
\hline & 9 & 0,604 & 0,30 & Valid \\
\hline & 10 & 0,631 & 0,30 & Valid \\
\hline \multirow{9}{*}{$\begin{array}{l}\text { Work Motivation } \\
\qquad(\mathrm{X} 2)\end{array}$} & 1 & 0,519 & 0,30 & Valid \\
\hline & 2 & 0,540 & 0,30 & Valid \\
\hline & 3 & 0,508 & 0,30 & Valid \\
\hline & 4 & 0,427 & 0,30 & Valid \\
\hline & 5 & 0,624 & 0,30 & Valid \\
\hline & 6 & 0,536 & 0,30 & Valid \\
\hline & 7 & 0,582 & 0,30 & Valid \\
\hline & 8 & 0,634 & 0,30 & Valid \\
\hline & 9 & 0,698 & 0,30 & Valid \\
\hline \multirow{10}{*}{$\begin{array}{c}\text { Employee } \\
\text { Performance }(\mathrm{Y})\end{array}$} & 1 & 0,678 & 0,30 & Valid \\
\hline & 2 & 0,672 & 0,30 & Valid \\
\hline & 3 & 0,648 & 0,30 & Valid \\
\hline & 4 & 0,646 & 0,30 & Valid \\
\hline & 5 & 0,614 & 0,30 & Valid \\
\hline & 6 & 0,676 & 0,30 & Valid \\
\hline & 7 & 0,609 & 0,30 & Valid \\
\hline & 8 & 0,601 & 0,30 & Valid \\
\hline & 9 & 0,684 & 0,30 & Valid \\
\hline & 10 & 0,777 & 0,30 & Valid \\
\hline
\end{tabular}

The table above shows that the calculated values in the Corrected Item Total Correlation column for each of the three variables above are stated as valid statements because the $r_{\text {count }}$ is greater than 0.30 . The reliability test result using SPSS (Statistical Packaged For Social Sciences) version 21 produced the Cronbach's Alpha $(\alpha)$ statistical test. A questionnaire is considered reliable if it has Cronbach's Alpha $(\alpha)$ more than 0.60 . The following table 4 shows reliability test results. 
The Influence of Leadership Style and Work Motivation on Employees Performance of Islamic Banks

Table 4. Instrument Reliability Test Results

\begin{tabular}{|c|c|c|c|}
\hline Variable & Reliability Coefficients & Cronbach Alpha & Description \\
\hline Leadership Style (X1) & 10 Item & 0,896 & Reliable \\
\hline Work Motivation (X2) & 9 Item & 0,847 & Reliable \\
\hline Employee Performance (Y) & 10 Item & 0,905 & Reliable \\
\hline
\end{tabular}

The table above shows that each variable has a Cronbach's Alpha $(\alpha)$ of more than $0.60(\alpha>0.60)$, which means that all variables, namely $\mathrm{X} 1, \mathrm{X} 2$, and $\mathrm{Y}$ are reliable. Thus data processing can be continued to the next level.

\section{B. Multiple Linear Regression Analysis}

Multiple linear regression analysis is a non-parametric statistical tool that functions to analyze the relationship and relationship between two or more different research variables, namely the dependent and independent variables [24]. It requires data consisting of several groups of measurement observations. Furthermore, from the results of this multiple regression analysis, it will be known whether there is a partial and simultaneous influence on the variables of Leadership Style (X1), Work Motivation (X2), and Employee Performance (Y). Based on the results of data processing using SPSS 21 for Windows, the results of multiple regression analysis are as follows.

Table 5. Multiple Linear Regression Analysis Results

\begin{tabular}{|c|c|c|c|c|c|c|c|c|}
\hline \multicolumn{9}{|c|}{ Coefficients } \\
\hline \multirow{2}{*}{\multicolumn{2}{|c|}{ Model }} & \multicolumn{2}{|c|}{$\begin{array}{c}\text { Unstandardized } \\
\text { Coefficients }\end{array}$} & \multirow{2}{*}{$\begin{array}{c}\text { Standardized } \\
\text { Coefficients }\end{array}$} & \multirow[t]{2}{*}{$\mathrm{t}$} & \multirow[t]{2}{*}{ Sig. } & \multicolumn{2}{|c|}{$\begin{array}{c}\text { Collinearity } \\
\text { Statistics }\end{array}$} \\
\hline & & $B$ & \begin{tabular}{|l} 
Std. \\
Error
\end{tabular} & & & & $\begin{array}{c}\text { Toleran } \\
\text { ce }\end{array}$ & VIF \\
\hline \multirow{3}{*}{1} & (Constant) & 14.337 & 5.649 & & 2.538 & .015 & & \\
\hline & LEADERSHIP STYLE & .532 & .151 & .560 & 3.525 & .001 & .494 & 2.026 \\
\hline & $\begin{array}{l}\text { WORK } \\
\text { MOTIVATION }\end{array}$ & .165 & .195 & .135 & .848 & .401 & .494 & 2.026 \\
\hline
\end{tabular}

The multiple linear regression analysis results in the table above were then entered into the multiple regression equation models is $Y=14,337+0,532 \times 1+0,165 \times 2$. The multiple linear regression equation above shows that the two independent variables (Leadership Style and Work Motivation) positively impact the dependent variable (Employee Performance). The above calculation results show that there is a positive constant of 14.337 which means that employee performance was increased by 14.337 if the variables of leadership style and work motivation are constant or zero (0). The leadership style regression coefficient (X1) of 0.532 was positive. The positive value $(+)$ on the leadership style variable has a unidirectional meaning. An increase in one unit of the leadership style variable (X1) increased employee performance by 0.532 if other variables were held constant. The regression coefficient of work motivation (X2) of 0.165 was positive. The positive value (+) on the work motivation variable had a unidirectional meaning. An increase in one unit of work motivation variable (X2) increased employee performance by 0.165 if other variables were considered constant.

\section{Hypothesis Testing Results}

\section{Simultaneous F Test}

To test the hypothesis, we used testing results that aim to know whether the independent variables contribute significantly to the dependent variable.

Table 6. F Test Result (Simultant Test)

\begin{tabular}{|rl|r|r|r|r|r|}
\hline \multicolumn{1}{|l|}{ Model } & Sum of Squares & \multicolumn{1}{|c|}{ df } & Mean Square & \multicolumn{1}{c|}{$\mathrm{F}$} & \multicolumn{1}{c|}{ Sig. } \\
\hline \multirow{2}{*}{1} & Regression & 381.588 & 2 & 190.794 & 17.627 & $.000^{\text {b }}$ \\
& Residual & 487.078 & 45 & 10.824 & & \\
& Total & 868.667 & 47 & & & \\
\hline
\end{tabular}

a. Dependent Variable: EMPLOYEE PERFORMANCE

b. Predictors: (Constant), WORK MOTIVATION, LEADERSHIP STYLE 


\section{The Influence of Leadership Style and Work Motivation on Employees Performance of Islamic Banks}

Based on the results of the ANOVA test (Analysis of Variance), or the F test, the Fount value of $17.62>$ Ftable 3.20 with a Sig value of 0.000 was smaller than alpha of 0.05 . Thus, these results meant that the variables of leadership style (X1), work motivation (X2), and employee performance (Y) simultaneously had a significant effect on increasing employee performance.

\section{Partial T-Test}

A partial t-test was used to test whether the independent variable really contributes to the dependent variable. The following is the T-test results in the coefficients table.

Table 7. T-Test Result (Partial Test)

Coefficients

\begin{tabular}{|c|c|c|c|c|c|c|c|c|}
\hline \multirow[t]{2}{*}{ Moc } & & \multicolumn{2}{|c|}{$\begin{array}{l}\text { Unstandardized } \\
\text { Coefficients }\end{array}$} & \multirow{2}{*}{$\begin{array}{c}\begin{array}{c}\text { Standardized } \\
\text { Coefficients }\end{array} \\
\text { Beta }\end{array}$} & \multirow[t]{2}{*}{$\mathrm{t}$} & \multirow[t]{2}{*}{ Sig. } & \multicolumn{2}{|c|}{$\begin{array}{l}\text { Collinearity } \\
\text { Statistics }\end{array}$} \\
\hline & & B & $\begin{array}{l}\text { Std. } \\
\text { Error }\end{array}$ & & & & Tolerance & VIF \\
\hline \multirow{5}{*}{1} & (Constant) & 14.337 & 5.649 & & 2.538 & .015 & & \\
\hline & LEADERSHIP SYLE & .532 & .151 & .560 & 3.525 & .001 & .494 & 2.026 \\
\hline & WORK & & & & & & & \\
\hline & MOTIVATION & & & & & & & \\
\hline & & .165 & .195 & .135 & .848 & .401 & .494 & 2.026 \\
\hline
\end{tabular}

a. Dependent Variable: EMPLOYEE PERFORMANCE

Based on the results of the statistical calculation of the T-test of the two independent variables included in the regression model, it can be seen that the Leadership Style (X1) obtained tcount $3.52>$ table 2.01 and has a significant value (sig) 0.001 in the coefficients table with a value of (significant level) 0.05 . The means was $0.001<0.05$. This value means that the Leadership Style variable (X1) has a significant influence on Employee Performance (Y). The magnitude of the effect can be seen in the Beta column. The magnitude of the influence of the $X 1$ variable on the $Y$ variable is $56 \%$.

Work Motivation (X2) obtained a count value of $0.848<$ table 2.01 and a significant value (sig) 0.40 greater than the value of 0.05. It means $0.40>0.05$. This value means that work motivation $(X 2)$ has an effect but is not significant on employee performance $(\mathrm{Y})$. The magnitude of the effect can be seen in the Beta column. The magnitude of the influence of the $\mathrm{X} 2$ variable on the $Y$ variable is $13.5 \%$.

\section{Coefficient of Determination}

The coefficient of determination analysis was conducted to find out how big the percentage of independent contribution (X) to the dependent variable (Y). From the results of calculations through the statistical measuring tool SPSS 21 For Windows, the coefficient of determination value is obtained as follows:

Table 8. Model of Summary

\section{Model Summary}

\begin{tabular}{|l|r|r|r|c|}
\hline Model & $\mathrm{R}$ & R Square & \multicolumn{1}{|c|}{$\begin{array}{c}\text { Adjusted R } \\
\text { Square }\end{array}$} & $\begin{array}{c}\text { Std. Error of the } \\
\text { Estimate }\end{array}$ \\
\hline 1 & $.663^{\mathrm{a}}$ & .439 & .414 & 3.28998 \\
\hline
\end{tabular}

a. Predictors: (Constant), WORK MOTIVATION, LEADERSHIP STYLE

b. Dependent Variable: EMPLOYEE PERFORMANCE

The output display of SPSS Model Summary R2 is 0.414 . This means that changes influence the variation of changes in the Employee Performance variable (Y) in the independent variable consisting of Leadership Style (X1), and Work Motivation (X2) of $41.4 \%$. While the rest $(100 \%-41.4 \%=58.6 \%)$ so, $58.6 \%$ is influenced by other factors not examined outside of this study.

\section{DISCUSSION}

The results of the test using multiple regression analysis with the help of SPSS 21 for Windows, the influence of leadership style and work motivation on employee performance at Bank Mandiri showed that it simultaneously had a positive influence on employee performance decisions. Likewise, the influence of each variable partially has an influence with a different magnitude 


\section{The Influence of Leadership Style and Work Motivation on Employees Performance of Islamic Banks}

of influence. For example, based on the Anova test data analysis results, with the results of Fount 17.62> Ftable 3.20 with a Sig value of 0.000 , which is smaller than alpha of 0.05 . Thus, this result means that the Leadership Style (X1) and Work Motivation (X2) variables simultaneously have a significant effect on Employee Performance (Y).

The Influence of Leadership Style on Employee Performance.

Based on the results of statistical tests, the value of count is $3.52>$ table 2.01 and has a significant value (sig) of 0.001 in the coefficients table with a value of (significant level) of 0.05 . It means $0.001<0.05$. This value means that the Leadership Style variable (X1) has a significant influence on Employee Performance (Y). The magnitude of the effect can be seen in the Beta column. The magnitude of the influence of the $X 1$ variable on the $Y$ variable is $56 \%$. These results can illustrate that respondents (employees) view that the leadership style possessed by a leader has been able to significantly influence employee performance.

In accordance with the respondents' answers, 28 respondents or 58.3\%, agreed with the statement that my leader did not prohibit his subordinates from working in teamwork. There were also 27 respondents or $56.3 \%$ who agreed with the statement that my leader was happy to receive suggestions from his subordinates. This can be considered as an incentive for employees to improve their performance.

The results of the study are in line with research conducted by Rakhmat Nugroho, which shows that the leadership style variable has a positive and significant effect on employee performance. ${ }^{2}$

\section{The Effect of Work Motivation on Employee Performance}

Based on the results of statistical tests, the t-count value was $0.84<$ ttable 2.01 , and the significant value (sig) 0.40 was greater than the -0.05 value. It means $0.40>0.05$. With this value, it means that the work motivation variable (X2) does not have a significant effect on employee performance $(Y)$. The magnitude of the effect can be seen in the Beta column. The magnitude of the influence of the $X 2$ variable on the $Y$ variable is $13.5 \%$. These results can provide an illustration that respondents (employees) view that the work motivation given by the leadership has not been able to influence employee performance significantly.

\section{CONCLUSION}

Based on the results discussed above, we concluded that the leadership style and work motivation significantly influence employee performance at Bank Mandiri, with a score of $56 \%$. Partially, the work motivation variable has a positive but not significant effect on employee performance, with a score of $13.5 \%$. Meanwhile, simultaneously, both independent variables of Leadership Style and Work Motivation significantly affect Employee Performance. Our findings contribute to better strategy in managing leadership and work motivation to enhance employees' work performance within banking industries.

\section{REFERENCES}

1) Cooley, C.H., Human Nature and the Social Order 1983, London: Routledge.

2) Caza, B.B., S. Moss, and H. Vough, From Synchronizing to Harmonizing: The Process of Authenticating Multiple Work Identities. Administrative Science Quarterly, 2018. 63(4): p. 703-745.

3) Paeleman, I. and T. Vanacker, Less is More, or Not? On the Interplay between Bundles of Slack Resources, Firm Performance and Firm Survival. Journal of Management Studies, 2015. 52(6): p. 819-848.

4) Nurdin, N., Institutional Arrangements in E-Government Implementation and Use: A Case Study From Indonesian Local Government. International Journal of Electronic Government Research (IJEGR), 2018. 14(2): p. 44-63.

5) Lepak, D.P., et al., A Conceptual Review of Human Resource Management Systems in Strategic Human Resource Management Research, in Research in Personnel and Human Resources Management, J.J. Martocchio, Editor. 2006, Emerald Group Publishing Limited. p. 217-271.

6) Luu, T.V., et al., Performance measurement of construction firms in developing countries. Construction Management and Economics, 2008. 26(4): p. 373-386.

7) Yankaskas, B., C. Klabunde, and R Ancelle-Park International comparison of performance measures for screening mammography: can it be done? Journal of Medical Screening, 2004. 11(4): p. 187-193.

8) Nurdin, N., R. Stockdale, and H. Scheepers, Coordination and Cooperation in E-Government: An Indonesian Local EGovernment Case The Electronic Journal of Information Systems in Developing countries, 2014. 61(3): p. 1-21.

${ }^{2}$ Nugroho, Analisi, 8 . 
9) de Waal, A. and M. Sivro, The Relation Between Servant Leadership, Organizational Performance, and the HighPerformance Organization Framework. Journal of Leadership \& Organizational Studies, 2012. 19(2): p. 173-190.

10) Arvonen, J. and G. Ekvall, Effective Leadership Style: Both Universal and Contingent? Creativity and Innovation Management, 1999. 8(4): p. 242-250.

11) Cabrera, E.F. and A. Cabrera, Fostering knowledge sharing through people management practices. The International Journal of Human Resource Management, 2005. 16(5): p. 720-735.

12) Yehezkel, O. and M. Lerner, Born to Be Wild? International Studies of Management \& Organization, 2009. 39(3): p. 631.

13) De Hoogh, A.H.B., L.L. Greer, and D.N. Den Hartog, Diabolical dictators or capable commanders? An investigation of the differential effects of autocratic leadership on team performance. The Leadership Quarterly, 2015. 26(5): p. 687-701.

14) Harms, P.D., et al., Autocratic leaders and authoritarian followers revisited: A review and agenda for the future. The Leadership Quarterly, 2018. 29(1): p. 105-122.

15) Foels, R., et al., The Effects of Democratic Leadership on Group Member Satisfaction:An Integration. Small-Group Research, 2000. 31(6): p. 676-701.

16) Yang, I., Positive effects of laissez-faire leadership: conceptual exploration. Journal of Management Development, 2015. 34(10): p. 1246-1261.

17) Moors, G., The effect of response style bias on the measurement of transformational, transactional, and laissez-faire leadership. European Journal of Work and Organizational Psychology, 2012. 21(2): p. 271-298.

18) Mir, A.M., Leadership in Islam. Journal of Leadership Studies, 2010. 4(3): p. 69-72.

19) Johnston, D.L., Islam and Human Rights: A Growing Rapprochement? American Journal of Economics and Sociology, 2015. 74(1): p. 113-148.

20) Reff Pedersen, A., K. Sehested, and E. Sørensen, Emerging Theoretical Understanding of Pluricentric Coordination in Public Governance. The American Review of Public Administration, 2011. 41(4): p. 375-394.

21) Nurdin, N., S.S. Pettalongi, and K. Yusuf. Knowledge Management Model in Syariah Banking. in 20185 th International Conference on Information Technology, Computer, and Electrical Engineering (ICITACEE). 2018.

22) Hall, L., C. Hume, and S. Tazzyman, Five Degrees of Happiness: Effective Smiley Face Likert Scales for Evaluating with Children, in Proceedings of the The 15th International Conference on Interaction Design and Children. 2016, Association for Computing Machinery: Manchester, United Kingdom. p. 311-321.

23) Frey, F., SPSS (Software), in The International Encyclopedia of Communication Research Methods. 2017. p. 1-2.

24) Nurdin, N., S.S. Pettalongi, and M.N. Ahsan. Implementation of Teaching Quality Assessment System Using Android. in 2019 5th International Conference on Science and Technology (ICST). 2019. 